\title{
Estudos de Educação Secundária - Fatôres e Conseqüências. Expansão do Ensino Secundário Brasileiro
}

\section{Geraldo Bastos Silva}

Significado da expansão do ensino secundário

A

atual estrutura do ensino secundário brasileiro data de 1942, quando foi promulgada a sua vigente «Lei Orgânica». Nesta lei, as finalidades do «ensino secundário» são formuladas nos seguintes têrmos:

«1. Formar, em prosseguimento da obra educativa do ensino primário, a personalidade integral dos adolescentes. 2. Acentuar e elevar, na formação espiritual dos adolescentes, a consciência patriótica e a consciência humanista. 3. Dar preparação intelectual geral que possa servir de base a estudos mais elevados de formação especial».

Para a compreensão da filosofia, ainda oficial, relativa ao ensino secundário brasileiro, mais expressivas do que a lei, em sua expressão literal, são as seguintes palavras da exposição de motivos com que foi submetida à sanção: «O ensino secundário se destina à preparação das individualidades condutoras. isto é. dos homens que deverão assumir as responsabilidades maiores dentro da sociedade e da nação, dos homens portadores das concepções e atitudes espirituais que é preciso infundir nas massas, que é preciso tornar habituais entre o povo».

Foi sob a vigência dessa finalidade de "preparação de individualidades condutoras», oficialmente expressa, que mais se acentuou o movimento de expansão quantitativa de nosso ensino secundário, iniciado desde o decênio anterior.

Como mostram os dados do quadro I, o crescimento do ensino secundário, representado pelos incrementos das matrículas em triênios, a partir de 1933, é não só ininterrupto como se realiza em aceleração. O incremento da matrícula em um triênio, é sempre superior ao verificado no triênio anterior, salvo no caso de 1939-1942, quando se observa um incremento de 44 mil, conitre 48 mil no triênio 1936-1939. A partir do triênio 1939-1942, a acelera- 
ção é pràticamente contínua: 44 mil, 57 mil, 79 mil, 102 mil, 102 mil, 128 mil.

QUADRO I

ENSINO MÉDIO NO PERIODO 1933-1957

\begin{tabular}{|c|c|c|c|c|c|c|c|c|}
\hline \multirow{2}{*}{ ANOS } & \multicolumn{2}{|c|}{ ENSINO SECUNDARIO } & \multicolumn{2}{|c|}{ ENSINO COMERCIAL } & \multicolumn{2}{|c|}{ ENSINO INDUSTRIAI. } & \multicolumn{2}{|c|}{ ENSINO AGRICOLA } \\
\hline & $\begin{array}{c}\text { Matricula } \\
\text { geral }\end{array}$ & $\begin{array}{l}\text { Unidades } \\
\text { escolares }\end{array}$ & $\begin{array}{c}\text { Matricula } \\
\text { geral }\end{array}$ & $\begin{array}{l}\text { Unidades } \\
\text { escolares }\end{array}$ & $\begin{array}{c}\text { Matricula } \\
\text { geral }\end{array}$ & $\begin{array}{l}\text { Unidades } \\
\text { escolares }\end{array}$ & $\begin{array}{c}\text { Matricula } \\
\text { geral }\end{array}$ & $\begin{array}{l}\text { Unidades } \\
\text { escolares }\end{array}$ \\
\hline 1933 & 66.420 & 417 & 19.493 & 388 & 3.936 & 40 & 387 & \\
\hline 1936 & 107.469 & 552 & 28.880 & 470 & 2.660 & 49 & 672 & \\
\hline 1939 & 155.588 & 782 & 42.574 & 493 & 3.916 & 48 & 504 & \\
\hline 1942 & 199.435 & 886 & 62.012 & 626 & 10.791 & 97 & 763 & 22 \\
\hline 1945 & 256.467 & 1.282 & 84.553 & 935 & 16.764 & 255 & 659 & \\
\hline 1948 & 335.882 & 1.663 & 84.072 & 774 & 18.691 & 384 & 2.601 & \\
\hline 1951 & 438.626 & 2.190 & 82.297 & 752 & 18.801 & 421 & 1.970 & \\
\hline 1954 & 540.902 & 2.510 & 103.709 & 883 & 19.102 & 421 & 1.143 & 35 \\
\hline 1957 & 668.845 & 2.945 & 139.278 & 1.058 & 19.131 & 401 & 3.671 & 64 \\
\hline
\end{tabular}

Fonte: Serviço de Estatistica da Educação e Cultura, "Sinopse Retrospectiva do Ensino no Brasil - 1871 1954, — Os dados relativos a 1957 são sujeitos a retificação.

O realmente impressionante crescimento das matrículas e das unidades escolares do ensino secundário, que os dados acima retratam, tem sido chamado dè «democratização», e a êle já se aplicou o epiteto criado por LOWNDES para denominar a expansão da educação inglesa: «revolução social silenciosa». (1) Sôbre isto, talvez não fôsse excessivo lembrar que revoluções, depois de feitas, muitas vêzes são consideradas journée des dupess... (2)

Mas, quanto a ser êsse crescimento, por suas causas e por seus efeitos, um fenômeno social, não há dúvida. É indiscutivel que, por trás da expansão do ensino secundário brasileiro, estão modificações que se vêm operando, nos últimos decênios, na vida nacional, das quais resultaram profunda alteração da fisionomia social, econômica e demográfica do país. A mudança estrutural da economia no sentido da industrialização, acompanhada de um aumento da riqueza nacional e refletida, antes de tudo, em crescente concentração urbana e tendência ao incremento das atividades terciárias e à maior mobili-

(1) G.A.N. Lowndes, The Silent Social Revolution, an Account of the Expansion of Public Education in England and Wales, 1895-1935. Londres: Oxford University Press, 1937.

(2) Sôbre o ensino secundário brasileiro, já tivemos oportunidade de escrever que "sua recente expansão - realizada sob a vigência de uma estrutura seletiva e inflexível que, no entanto,não consegue prevalecer sôbre o desejo interesseiro ou demagógico de criar maintes oportunidades de educação por meio de emprêsas às vêzes pouco escrupulosas, de "educandários gratuitos" ou de ginásios públicos instalados de afogadilho e dispondo de verbas insuficientes - resultou na sua transformação em mecanismo de desencaminhamento de parcela considerável de nossa juventude das atividades realmente produtivas (GERALDO Bastos Silva, Educação e Desenvolvimento Nacional, Rio: ISEB, 1957, p. 37). 
dade social vertical, são fatos claramente relacionados com a expansão quantitativa do ensino secundário. (Quadro II)

À iuz de suas correlações sócio-econômicas, a tendência expansiva do ensino secundário é a manifestação particular de um fato geral, que é a crescente procura de ensino médio em todos os seus ramos. E êste fato geral tem a significação indiscutivel de uma necessidade maior de uma edı:cação formal mais demorada e mais completa do que aquela que a escola primária deveria proporcionar. $\mathrm{O}$ aumento da procura do ensino secundário representa maior necessidade daquela educação básica de que a escola priméria constitui a primeira fase, ou seja, traduz um imperativo mais definido de ecucação pos-primária ou média.

De fato, não se expandiu, apenas, o ensino secundário. Cresceram, também, os outros ramos do ensino de segundo grau, como o comercial e o

QUADRO II

EVOLUÇÃo DO ENSINO MÉdio, DAS OPORTUNidADES DE TRABALHO, DA POPULAÇão

E DA RENDA NACIONAL NO PEŔ́odo 1940-1950

\begin{tabular}{|c|c|c|c|}
\hline \multirow{2}{*}{ DISCRIMINAÇÃO } & \multirow{2}{*}{1940} & \multicolumn{2}{|c|}{1950} \\
\hline & & $\begin{array}{l}\text { VALORES } \\
\text { ABSOLUTOS }\end{array}$ & $\begin{array}{c}\text { fNDICES } \\
(1940=100)\end{array}$ \\
\hline MATRÍCULA GERAL (1) & & & \\
\hline Curso secundário ............. & 155.588 & 365.851 & 235 \\
\hline Curso comercial............ & 45.932 & 88.082 & 192 \\
\hline Curso industrial (2) $\ldots \ldots \ldots$ & 13.262 & 36.754 & 277 \\
\hline OPORTUNIDADES DE TRAJALHO (3) & & & $=$ \\
\hline No comércio............................... & 800.920 & 1.073 .921 & 134 \\
\hline $\mathrm{Na}$ indústria $\ldots \ldots \ldots \ldots \ldots \ldots \ldots$ & 1.400 .056 & 2.231 .198 & 159 \\
\hline 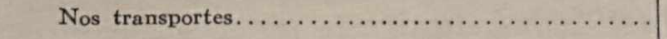 & 473.676 & 697.042 & 147 \\
\hline Na administração pública...$\ldots \ldots \ldots \ldots \ldots \ldots \ldots$ & 234.860 & 260.767 & 111 \\
\hline 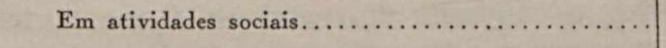 & 205.576 & 434,315 & 211 \\
\hline 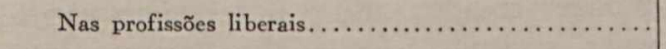 & 51.956 & 66.951 & 129 \\
\hline POPULAÇÃo NA IDADE DE 14 A 19 ANOS (3) $\ldots \ldots \ldots \ldots \ldots$ & 5.431 .466 & 6.676 .236 & 123 \\
\hline 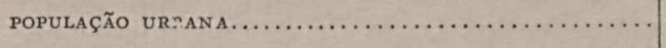 & 12.880 .182 & 18.775 .779 & 146 \\
\hline 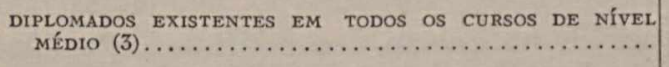 & 358.686 & 987.162 & 275 \\
\hline RENDA NACIONAL $(4) \ldots \ldots \ldots \ldots \ldots \ldots \ldots \ldots \ldots \ldots \ldots \ldots \ldots \ldots \ldots \ldots$ & 160.940 & 258.750 & 171 \\
\hline
\end{tabular}

(1) Dados referentes ao ensino público e particular em 1939 e 1949.

(2) Escolas Federais, equiparadas e reconhecidas. Dados referentes aos anos de 1943 e 1953 (estimativa).

(3) Na data dos Censos Demográficos.

(4) Em bilhões de cruzeiros, em 1941 e 1951, com o valor do cruzeiro de 1941 retificado na base de 1951; índice: $1941=100$

Fonte: Américo Barbosa de Oliveira, "O ensino, o trabalho, a população e a renda", Rev. Bras. de Est. Peda gógicos, n. 53, pp. 92,94 e 97. 
industrial, e houve, também, como não poderia deixar de ocorrer, porquanto as fôrças sociais, deflagradas pelas transformações antes aludidas, atuam sôbre o sistema escolar todo, certo crescimento do ensino primário e superior. (Quadro III)

QUADRO III

EVOLUÇÃO DOS ENSINOS PRIMÁRIO E SUPERIOR E DA POPULAÇÃO NO PERÍODO $1940-1950$

\begin{tabular}{|c|c|c|c|}
\hline \multirow[b]{2}{*}{ DISCRIMINAÇÃO } & \multirow[b]{2}{*}{1940} & \multicolumn{2}{|c|}{1950} \\
\hline & & $\begin{array}{l}\text { VATORFS } \\
\text { ABSOLUTOS }\end{array}$ & $\begin{array}{l}\text { INDICFS } \\
(1940=100)\end{array}$ \\
\hline Matrícula geral no ensino primário (1)... & 3.205 .753 & 5.108 .924 & 159 \\
\hline População de 7 a 12 anos de idade (2). & 6.748 .575 & 8.071 .452 & 120 \\
\hline Matrícula geral no ensino superior (1)... & 21.235 & 37.584 & 177 \\
\hline População urbana (2) ................. & 12.880 .182 & 18.775 .779 & 146 \\
\hline
\end{tabular}

(1) Dados referentes ao ensino público e particular em 1939 e 1949.

(2) Nas datas dos Censos Demográficos.

Fonte: Revista Brasileira de Fstudos Pedagógicos, cit., pp. 89 e 94.

Todavia, mais constante e pronunciadamente do que qualquer outro ramo ou grau de educação, a tendência expansiva afetou o ensino secundário. Como se vê do quadro I, a tendência nesse sentido, com relação ao ensino secundário, não sofre nenhuma interrupção a partir do ano inicial considerado. Diversamente, ainda que a tendência verificada nos ensinos comercial e agrícola seja, no conjunto, expansiva, há certas oscilações. No ensino comercial, há certa diminuição da matrícula geral e das unidades escolares entre 1945 e 1951. No ensino agrícola, a matricula sofre um primeiro declínio em 1939; um segundo em 1945, compensado pelo grande aumento verificado entre 1945 e 1948, mas retomado a partir do triênio seguinte; os dados de 1957 , indicam grande melhoria em relação a 1954. A tendência ao crescimento do ensino secundário sòmente encontra paralelo, significativa e auspiciosamente, no ensino industrial, onde igual tendência ascendente da matrícula é constante a rartiı de 1936, desde quando começa a ser compensado o decréscimo verificado a partir de 1933. Deve-se observar, contudo, que o alto incremento a partir de 1942 é devido a que, desde então, as estatísticas dêsse ensino passara”n a englobar cursos anteriormente classificados como de ensino doméstico.

O crescimento verificado, em especial, no ensino secundário, dentro do conjunto do ensino médio, é um fato singular. Com efeito isolado dos referidos fatôres de ordem social, tal crescimento, podemos dizer, não deveria assumir êsse relêvo especial. Não diremos que devesse ocorrer um impressionante desenvolvimento do ensino industrial, maior do que o verificado. A verdade é que se deveria esperar sucedesse o que efetivamente está sucedendo, isto é, qu o suprimento de mão-de-obra especializada, necessária à industrialização, continui a fazer-se, em sua maior parte, por meios mais rápidos do que a formação profissional dada em escolas especialmente destinadas a êsse fim. 
No entanto, em face do aumento das oportunidades de ocupação nas atıvidades terciárias, nada teria de surpreendente se tivesse havido um crescimento, tem maior do que o verificado, na procura do ensino comercial, o qual, para algumas dessas atividades, mais diretamente prepara.

A causalidade especifica do crescimento do ensino secundário, portanto, nãc reside nos fatôres de ordem social e econômica antes apontados. Êstes fatôres, constituem a causalidade genérica, ou melhor, criam, apenas, certas condições, dentro das quais atuam fatôres específicos responsáveis diretos pelo fato de que a demanda de ensino médio produza o crescimento, mais forte do que o dos demais ramos dêsse nível, do ensino secundário. Ou, transpondo os têrmos mas não alterando a igualdade: o crescimento, em particular, do ensino secundário, resulta de que fatôres especificos atuam no sentido de torná-lo ponto de menor resistência à ação dos fatôres gerais.

Prestígic do ensino sacundário e condições administrativas do seu crescimento

A análise dos fatôres específicos do crescimento do ensino secundário, deveria esclarecer, inicialmente, a motivação da intensa procura dêsse ensino, de que tal crescimento é a objetivação. Não temos conhecimento de qualquer estudo especialmente destinado a êsse fim. Parece-nos todavia acertada a idéia, geralmente aceita, de que a motivação da procura- do curso secundário, $\mathrm{em}$ detrimento dos demais ramos do ensino médio, reside bàsicamente no seu maior prestígio. Adotando-se essa idéia, ao menos como hipótese de trabalho, tratar-se-ia de determinar a situação objetiva e os motivos mediatos ou indiretos que estariam por três dessa valorização positiva mais acentuada do ensino secundário. E dos resultados a que, muito provàvelmente, se chegaria em tal pesquisa. podemos considerar indicação talvez suficientes aquêles obtidos num inquérito sôbre «Escolha ocupacional e origem social de ginasianos de São Paulo». (3)

Dos ginasianos abrangidos por êsse inquérito, que totalizaram 1.353, apenas $8,4 \%$ tinham pais cuja ocupação era manual. «A maior percentagem $(40.5 \%)$ dos alunos provém de familias de comerciantes, industriais e pessoas que ocupam altas posições administrativas, vindo em segundo lugar $(24,2 \%)$ os filhos de empregados de escritório, vendedores e outros do mesmo nivel. Perto de dezenove por cento do total $(18,6 \%)$ é constituido de alunos cujos pais têm uma das profissões que tradicionalmente gozam de grande prestígio, e $8,3 \%$ de filhos de pessoas que exercem as demais profissões». (4)

Do total de alunos pesquisados, $88,6 \%$ consideraram ocupação ideal uma das seguintes: engenheiros $(41,5 \%)$, médico $(17,2 \%)$, advogado $(9,1 \%)$, ou outras profissões liberais $(18,8) \%$. E como ocupação preferencial, no caso de inteira liberdade de escolha, indicaram, na percentagem de $80,0 \%$, as nesmas. A alta estimação da profissão de engenheiro é significativa, mas perfeitamente compreensivel num meio mais industrializado do que o

(3) Juarez Rubens Brandão Lopes, Escolha ocupacional e origem social de ginasianos em São Paulo, Educação e Ciências Sociais, Boletim do Centro Brasileiro de Pesquisas. Educacionais, n. ${ }^{\circ}$ 2, agôsto de 1956, pp. 43-62.

(4) Trabalho citado, p. 49. 
geral em nosso país, como é São Paulo. E justificaria outras pesquisas, em cidades de regióes onde a transformação estrutural no sentido da industrialização ainda não afetou tão profundamente a tradicional fisionomia ecorômica e social brasileira.

Todavia, o resultado obtido no inquérito social, que estamos analisando, que é de maior interêsse para nós, diz respeito às relações entre as ocupações ideais e preferidas, e a classe ocupacional do pai. Sôbre isto diz o autor nas conclusões:

«Não há quase associação entre a escolha da ocupação provável (preferida) e o status sócio-econômico dos pais (indicado pela profissão paterna e pela nacionalidade os pais): os individuos de quase todos os níveis ocupacionais indicaram aproximadamente na mesma proporção a intenção de exercer as quatro profissões liberais de grande prestigio (...). É importante notarmos que as percentagens de escolha dessas profissões liberais não são muito menores entre os de origem estrangeira do que os de pais brasileiros, o que parece indicar uma assimilação aos valores brasileiros.» (5)

Os resultados dessa pesquisa deixariam perfeitamente confirmada, ao que parece, a suposição de que é o prestígio do ensino secundário a motivação básica da intensificação da sua procura. E êsse prestígio por sua vez, se relaciona com o prestigio de determinada situação de classe e de certas jrofissões. É o fato de que o ensino secundário apareça como instrumento não só de conservação da posição de classe daqueles que nascem na parte superior da pirâmide social, mas, também, de melhoria e ascensão social, que determina a sua crescente procura.

Mas, é evidente que, se o caráter de seleção ou peneiramento que é o pressuposto inecessário de um ensino que se destina a minorias, a um escol, a futuras «individualidades condutoras», se efetivasse plenamente, bem menor teria sido o crescimento do ensino secundário. Antes de focalizar êste aspecto, em si mesmo, o qual nos leva, realmente, à raiz dos problemas do ensino secundário, devemos acentuar um outra que, de certo modo, constitui o seu reverso. Aumentou a procura do ensino secundário, mas, em resposta à demanda, cresceu também a oberta. Cresceu a matrícula, mas cresceu também o número de estabelecimentos de ensino secundário. É verdade que a matrícula média por unidade escolar aumentou de 159,2 alunos, em 1933, para 225,0 em 1942 e 215,4 em 1954. Mas, enquanto em 1933, das 417 unidades escolares, sòmente 20 eram de segundo ciclo (o então «curso complementar»), em 1942, das 886 unidades escolares, 138 eram de segundo ciclo, e, em 1954, das 1.785 unidades escolares, 537 eram de segundo ciclo. O aumento da matrícula média por unidade escolar, entre 1933 e 1942, correspondeu a uma ampliação do estágio escolar de muitos estabelecimentos. Entre 1942 e 1954, o aumento do ensino secundário já não se deveu tanto ao da matrícula média por unidade.

Dessa forma, o crescimento do ensino secundário representou, sobretudo, sua maior difusão, não só pelo aumento do número dos estabelecimentos, em si mesmo, mas, também, pelo fato de que essa multiplicação 
representou aumento da área geográfica servida de ensino secundário. De fato, nas grandes capitais a escola secundária deixou de ser uma instituição ecològicamente ligada à zona central e aos bairros mais próximos, mais densos ou mais prósperos. E, para o conjunto do país, ainda que não disponhamos de dados que permitam comparações a prazo mais longo, vemos que o crescimento dos estabelecimentos situados no interior do país tem acompanhado o do número total de estabelecimentos, entre os anos de 1954 e 1957. Dos novos 435 estabelecimentos surgidos entre êsses dois anos, 316 se situavam fora das capitais. De outra parte, enquanto dos 2.232 municípios existentes no Brasil, em 1954, possuíam estabelecimentos de ensino secundário $31,1 \%$; dos 2.455 municipios existentes em 1957, estavam nas mesmas condições $36,6 \%$.

As implicações pedagógicas dessa maior difusão do ensino secundário serão oportunamente consideradas. No momento, interessa-nos, sobretudo, o que podemos chamar as condições administrativas dêsse fato. Por que se deu essa maior penetração do ensino secundário pelo interior do país, com o aparecimento de ginásios e colégios em municípios onde, em certos casos, tal coisa, em face da modéstia das comunidades, surpreende? Como foi possivel que, também nas metrópoles, em subúrbios habitados por populações de parcos recursos econômicos, se instalassem escolas secundárias?

Considerando que, até hoje, mais de $65 \%$ dos alunos estão matriculados em estabelecimentos particulares, a resposta a essas perguntas envolve uma primeira verificação: a de que o atendimento da procura de ensino secundário não exigiu grandes inversões, nem despesas de manutenção acima da capacidade de pagamento de amplos setores da classe média. O contato direto com os estabelecimentos confirmará essa verificação. Freqüentemente os prédios são modestos, as instalações e o aparelhamento também não pecam por excesso de luxo. A organização é singela. $O$ pessoal é constituído pelo diretor (em geral o proprietário), pessoal auxiliar pouco numeroso e professôres. Êstes últimos ganham vencimentos reduzidos, calculados à base do número de aulas dadas. $\mathrm{O}$ ensino é meramente expositivo. A escola funciona em dois ou mais turnos, para turmas diferentes.

Em tais condições - há as exceções - é hatural que a qualidađe e a eficiểncia do ensino não sejam, de modo geral, satisfatórias. Mas, oficialmente, o ensino secundário está preparando «individualidades condutoras». E da finalidade legal do ensino secundário deveria, lògicamente, decorrer uma política administrativa destinada a criar condições para a realização dessa finalidade. Assim, foi a falência da administração pública em efetivar, através de sua ação reguladora - já que não o fêz através de ação criadora de estabelecimentos públicos em número suficiente, - a finalidade que ela mesma promulgou, que condiciona a «democratização» do ensino secundário, esta joutrnée des dupes.

Não foi a falência de um administrador, ou de vários, mas de um sistema. Em conjunto, a administração federal se esforçou por constituir,

(6) Cf. as Sinopse Estatíticas do Ensino Médico, do Serviço de Estatítica da Educação e Cultura, relativas aos anos de 1954 e 1957. 
pelos meios legais que lhe eram postos às mãos, uma estrutura escolar voltada ao objetivo que se considera próprio do «ensino secundário». Baixou regulamentos destinados a prover os ginásios e colégios dos requisitos. materiais necessários ao cumprimento de sua missão. Procurou criar condições para que o exercício do magistério se estabelecesse profissionalmente, primeiro controlando o ingresso na profissão, depois criando escolas de formação. Fixou processos de funcionamento. Doutrinou, regulamentou, fiscalizou. Houve momentos em que vacilou, houve momentos de fraqueza. De modo geral, no entanto, trabalhou. Mas, na verdade, não pôde executar a política que a coerência com a lei básica do ensino secundário exigia. (7)

$\mathrm{E}$ foi na ausência dessa política que o ensino secundário cresceu. Cresceu por causa de seu prestígio e porque era um meio fácil de atender, mal ou bem, à maior exigência de educação formal para adolescentes. Cresceu como as condições objetivas o exigiam e como as mesmas condições o permitiam. Cresceu apesar de a finalidade que buscava, e a organização pela qual se pautava o tornarem impróprio para função real que era chamado a preencher. Cresceu renegando aquilo que, oficialmente, era o seu ideal, simulando o, deformando-o, às vêzes, até mesmo onde bem poderia tentar sèriamente sua realização autêntica.

\section{Do ensino primário ao secundário: a ausência de seleção}

Dentre as condições que serviram de base ao crescimerito do ensino secundário brasileiro, bem como limitaram a realização do ideal que o deveria orientar, está a situação do ensino primário. Tocamos, aqui, o problema que diz respeito à articulação daqueles que devem constituir dois niveis sucessivos de um processo essencialmente contínuo, e que, se se diferenciam com base em caracteres próprios do desenvolvimento individual, tal diferenciação sòmente se acentua em razão de motivos de ordem prática ou administrativa. Enquanto condição do desenvolvimento do ensino se-

(7.) Um dos aspectos da administração federal do ensino secundário em que, de modo mais saliente, se têm revelado as suas vacilações e deficiências, é o relativo à inspeção. O problema de efetivar um contrôle centralizado, num pais da extensão do Brasil, de uma rêde escolar em expansão, é realmente difícil. Disto e da incapacidade de a administração enfrentar sèriamente o problema, resultaram as caracteristicas de mero contrôle formal queaté recentemente predominava na inspeção federal. A partir da criação das Inspetorias. Secionais estas caracteristicas tendem a mudar, mas há, ainda, um amplo caminho a ser percorrido nessa direção. Sôbre a história do problema da inspeção do ensino secundário e deoutro aspecto da administração federal dêste ensino, veja-se o trabalho do autor: Apontamentos para a história da administração federal do ensino secundário. Campanha de Aperfeiçoamento e Difusão do Ensino Secundário, Documentário n.$^{\circ}$ 9, janeiro de 1957 . A êste trabalho há uma retificação a fazer, no que se relaciona com os antecedentes da descentralização da inspeção federal. Referimo-nos à circunstância de esta providência indispensável ter sido preconizada e estudada pelo professor RoBERTO BANDEIRA AcIoli, quando Diretor do Ensino Secundário do Ministério da Educação e Cultura. Assim, ao lado dos professôres Paulo Sá. Armando Hildebrand e Gildásio Amado, aos quais se devem o início e a consolidação do sistema descentralizado de inspeção do ensino secundário, é um dever elementar de justiça colocar o professor RoBerto Acioli. Sôbre a posição do Govêrno federal emface do ensio secundário, até 1930, veja-se também o trabalho do autor: Ação federal sôbre o ensino secundário e superior na revista "Studia" (órgão da Congregação do Colégio Pedro II), n 7, 1956, pp. 81-135. 
cundário, a situação do ensino primário é, entre nós, uma condição que evolui fora do âmbito do poder regulador ao qual está sujeito o ensino secundário. Êste é o poder federal, enquanto o ensino primário é atribuição dos Estados.

De qualquer modo, a evolução quantitativa e qualitativa do ensino primário teria de refletir-se, necessàriamente, no ensino secundário. Na verdade, jamais teve, entre nós, a mesma significação e vigência que apresentou ma Europa, a prática de, anexo às escolas de tipo secundário, funcionar um ensino elementar preparatório a êste último. Essa prática, que realizava, no nivel elementar, a divisão vertical do sistema escolar total em dois ramos ou sistemas paralelos, correspondentes, cada um, à educação das classes superiores e à educação das massas populares, é um fenômeno tìpicamente europeu. Não era da escola primária - école primair, na França, Volkschule, ou escola popular, na Alemanha - que provinham os alunos da escola secundária. E sim das classes preparatoires ou Vorschulen, anexas às próprias escolas secundárias.

Mas, se essa prática traduzia segregação de classes sociais, ela também correspondia à exigência pedagógica de se proporcionar aos alunos destinados ao ensino secundário, desde cedo, um treinamento escolar de natureza especial. E tanto assim é que, quando se iniciou o movimento da escola única, que visava a acabar, no nível elementar, com a diferença de tipos de educação de acôrdo com a classe social das respectivas clientelas, assumiu relêvo o problema de asšegurar aos alunos intelectualmente bem dotados - independentemente de suas classes sociais de origem - uma educação de acôrdo com suas aptidões, e isto não só para seu benefício individual como, também, para o maior proveito social. (8)

Compreendemos, assim, que a qualidade da educação primária tem decisiva importância para o ensino secundário. E não só a qualidade, como o tipo da educação elementar, na acepção do têrmo tipo que desenvolveremos noutra oportunidade. E se o tipo da educação elementar é social e culturalmente determinado, como veremos, não o é menos a sua qualidade. Não nos cabe tentar a análise das condições sócio-culturais da escola primária no Brasil. Baste-nos assinalar que tais condições não têm sido de molde a permitir, em qualquer época, um ensino primário realmente satisfatório. De certo modo, essas condições têm sido as mesmas que afetam a escola secundária e que fazem da escola em geral, no Brasil, uma instituição desenraizada nas comunidades, incompreendida, e, por isso, de eficiência educativa, em geral, de baixo nível.

As transformações sociais e econômicas dos últimos decênios, que assinalamos com referência ao ensino secundário, têm afetado, igualmente, o ensino primário. Entre 1933 e 1953, êle cresceu de quase três vêzes quanto às unidades escolares, e de mais de duas vêzes e meio quanto às matriculas. A constância dêsse crescimento só encontra paralelo perfeito no crescimento do ensino secundário. Ao lado da expansão quantitativa, no

(8) Veja-se: Lorenzo Luzuriaga, A Escola Ürica, São Paulo: Companhia Melhoramentos, 1934; Estevam PINTo, O Problema da Educação dos Bem Dotados, São Paulo: Companhia Melhoramentos, 1933. 
entanto, a transformação das condições sociais, econômicas e demográficas tem gerado ou acentuado problemas a que a natureza um tanto anacrônica da escola primária brasileira não tem permitido dar solução. (9) Dentre êsses problemas, avulta o da evasão escolar, que se exprime através de dados numéricos com os seguintes: de 1.100 .129 alunos que ingressaram na $1^{\text {a }}$ série primária, em 1945 , sòmente 90.657 conseguiram ser aprovados na $3^{\text {a }}$ série em 1947, e aprovados na $4^{a}$ série, de 1948, apenas 54.297. (10)

Quando se comparam dados como êstes com os relativos ao ingresso no ginásio, torna-se evidente em que sentido a situação do ensino primário afetou e tem sido afetada pelo crescimento do ensino secundário. Assim, em 1942, concluiram a $5^{a}$ série primária menos de 30 mil alunos, enquanto que, no ano seguinte, se matriculavam na primeira série ginasial $62 \mathrm{mil}$ alunos. De ano a ano, enquanto cresce a matrícula inicial no ginásio, diminui o múmero de matriculados na $5^{a}$ série primária. Em 1949 e 1950 , os números eram, respectivamente, 11 mil e $100 \mathrm{mil}$. A tendência dominante, no ensino primário, é no sentido do desaparecimento dessa série final e do encurtamento de duração da escolaridade, a qual, na maioria das escolas, não excede a 3 séries escolares. Assim, a conclusão a tirar é a do acêrto da denominação que Lourenço Filho aplicou aos alunos da escola secundária: «alunos improvisados». (11)

Nas palavras de LouREnço FilHo, «hegamos, pois, a êste triste resultado: só fazem estudos até o $5^{\circ}$ ou $4^{\circ}$ ano primário os meninos brasileiros cujas familias pretendem levá-los a estudos ulteriores». Não dispomos de inquéritos sôbre a escolaridade primária de amostras representativas dos alunos que ingressam no ginásio. Assim, somos obrigados a admitir que a interpretação de Lourenço FilHo é, possivelmente, correta. Mas, também podemos supor que ela se aplique sòmente a uma parte dos neoginasianos. Tão comum quanto o prolongamento do curso primário com vistas à continuação dos estudos em nível secundário, será, talvez, precisamente o encurtamento do estágio escolar primário, para um imediato ingresso no prestigioso ginásio. É possível que a primeira hipótese se verifique, especialmente, no caso de filhos de familias em melhor situação econômica, ou melhor capacitadas para orientar a educação dos filhos. $\mathrm{Na}$ outra hipótese, a atração do ginásio opera na qualidade de mecanismo de drenageni, a impedir que os alunos completem o curso primário.

Mas se tal ocorre, pelo menos em parte, por que ocorre? Evidentemente porque, à entrada do ginásio, não há, operando em sentido oposto, o mecanismo de seleção que seria o pressuposto lógico ou a primeira exigência pedagógica de um ensino de «preparação de individualidades condutoras». Foi, incontestàvelmente, à falta de uma verdadeira seleção dos aspirantes

(9) Vejam-se, entre muitos outros trabalhos, os de J. Roberto Moreira, O desvittuamento da escola primária urbana pela multiplicação de turnos e pela desarticulação com o ensino médio, "Rev. Bras. de Est. Pedag.", n 56, e Os problemas do ensino elementar no Brasil, mesma revista, n. ${ }^{\circ} 64$.

(10) Moysés I. Kesser, A evasão escolar no ensino primário, "Rev. Bras. de Est. Pedagógicos", n. ${ }^{\circ} 56$, pp. 53 e segs.

(11) Lourenço Filho, Problemas de educação secundária, Campanha de Aperfeiçoamento e Difusão do Ensino Secundário, Documentário n. ${ }^{\circ} 4$, maio de 1954 , p. 13. 
ao ensino secundário, que êste ensino se expandiu, que proliferaram os ginásios e se multiplicaram as matrículas. A atração do ginásio, não encontrando a barreira de uma seleção adequada, que possibilitasse o desvio. da demanda de ensino médio na direção dos outros ramos que não o secundário, não tinha, por outra parte, a compensação de uma valorização fortemente positiva do ensino primário. Ao contrário disto, a concentração urbana, agravando a insuficiência quantitativa do ensino primário público, consolidava um tipo de escola primária agregada a um ginásio, voltada inteiramente à preparação ao «exame de admissão» e cuja existência, de início, era a etapa preliminar para o funcionamento futuro do curso ginasial, mediante a criação de uma clientela eventual.

Assim, a «democratização do ensino secundário», entre nós, em vez de representar a extensão progressiva da escolaridade formal, como prolongamento de um ensino primário crescentemente difundido e eficiente, se correlacionou com a estagnação dêste último ensino ou, ao menos, com a sua insuficiência quantitativa e com o empobrecimento de seı alcance e conteúdo, em vista dos quais cada vez maior se fazia seu desprestigio. E foi dêsse modo que o ensino secundário pôde crescer, sem que êste crescimento conseguisse forçar até hoje, a reestruturação necessária ao seı ajustamento à nova situação de um ensino que não é mais o de um minoria selecionada. Mas, ao ponto em que a situação chegou, a manutenção de sua estrutura atual assume caráter insuportável, pelo ônus que representa para o desenvolvimento do país, senão pela deformação em massa, que realiza, de quantidades cada vez maiores de adolescentes.

\section{Conseqüências pedagógicas da expansão do ensino secundário}

A expansão do ensino secundário envolve, necessàriamente, numerosas: conseqüências para o funcionamento do mesmo. Concebido na forma em que a sua legislação o concebe, o ensino secundário é, pedagògicamente, um. tipo de ensino seletivo, destinado a escolher e formar a minoria, a elite. De outro lado, ao conceito pedagógico de ensino seletivo corresponde a. idéia de um ensino ajustado especificamente a uma determinada situação de classe, ainda que as idéias democráticas exijam que sirva êle, também, de mecanismo pelo qual os nascidos em outras classes, que não aquela que toma como ponto principal de referência, a esta possam ascender. Isto, no entanto, não exclui a idéia da finalidade socialmente seletiva de tal ensino. (12)

Como diz Lourenço Filho, «para que, do ponto de vista social, exista ensino secundário satisfatório, será preciso que haja onde selecionar alunos, ou enfim, que a educação prímária tenha larga difusão. A entrada para o curso secundário já deverá representar certa seleção quanto a capacidades reais e quanto à «maturação» que os candidatos apresentem. De outra

(12) Henri Simon, em trabalho a que nos referimos mais demoradamente em outra oportunidade, no qual defende a "especificidade" do ensino secundário, diz que êste "se dirige a adolescentes que se beneficiam ao mesmo tempo de dons pessoais e de apoios sociais, venham êstes últimos de sua familia ou do Estado". ("La Coordination des Enseignements du Second Degré. Enquête Internationale", Paris: Societé des Nations, Institut Internacional de Coopétion Intellectuelle, 1938, p. 146). 
forma, será inútil pensar em ter bons ginásios e, ainda mais, bons colégios. A questão não é, apenas, a de aquisição de conhecimentos, e podiamos até dizer, da aquisição de fórmulas verbais de conhecimentos. Não. A questão é de maturidade intelectual, de formação, que só a idade de 12 anos, e só excepcionalmente, a de 11 , podem dar. E, podem dar, quando o ensino primário haja sido bem orientado.»

A ausência de seleção, dêsse modo, já é, por si sòzinha, um fator a criar consequiências pedagógicas para o ensino secundário seletivo. Com o crescimento incontrolado da matrícula, que disso decorre, a massa dos alunos torna-se crescentemente heterogênea, quer do ponto de vista do preparo escolar anterior, quer do ponto de vista da maturidade. E, enquanto a maturação, fator intrínseco do desenvolvimento, e a aprendizagem, aspecto da influência ambiental, de certo modo se compensam, o resultado não é menos desfavorável ao trabalho do ensino secundário: a seleção inadequada, à porta da escola secundária, faz com que ingressem alunos pouco amadurecidos, que se submeteram a um preparo escolar intensivo, e alunos amadurecidos, nos quais esta condição compensa uma escolaridade anterior sumária ou mal orientada. A heterogeneidade da massa discente, dêsse modo, passa a ser a característica dos alunos do ensino secundário, quer no sentido geral, quer do ponto de vista da escolaridade anterior, quer, finalmente, quanto aos niveis de maturidade.

De outra parte, para acentuar essa característica de heterogeneidade de seu discipulado, com o seu crescimento o ensino secundário perde o caráter socialmente seletivo. Em vez de os alunos provirem de extratos sociais moderadamente desnivelados, acentuam-se na população escolar as disparidades de niveis sociais, com a decorrência de a crescente heterogeneidade de condições extra-escolares de motivação e de experiência cultural somar-se à heterogeneidade de niveis de adiantamento escolar e de maturidade psicológica. Na medida em que o crescimento do ensino secundário envolve a ampliação da área geográfica servida do mesmo, a diversidade de experiência cultural extra-escolar decorre, também, da diversidade das condições de vida das comunidades donde provêm os alunos. Se o crescimento do ensino secundário tivesse manifestado uma política definida de educação, e inão a irrupção desordenada, na superestrutura escolar, das transformações sócio-econômicas infra-estruturais, êle se teria acompanhado de medidas administrativas destinadas a neutralizar ou atenuar as expressões mais ostensivas das diferenças de niveis sociais dos alunos, ou seja, de medidas assistenciais, adequadas. Se tal não ocorreu, não se poderá, no entanto, desconhecer aquelas expressões das diferenças de niveis sociais que, por serem menos ostensivas, nem por isso são de menores repercussões pedagógicas.

A conseqüência global do complexo de fatôres que determinaram, facilitaram ou estimularam o crescimento do ensino secundário, é que êste não opera com o caráter, que formalmente se lhe atribui, de uma educação seletiva, isto é, com o caráter de uma educação que escolhe os melhores e os prepara, dentro de um sentido de formação da personalidade, para as funções de liderança social. Êle passa a ser seletivo, no entanto, no pior

(13) Lourenço FILHo, Problemas da educação secundária, cit. p. 15. 
sentido da expressão. Recruta seus alunos mediante um precário «exame de admissão», e deixa que, no decorrer do estágio escolar, atuem fatôres casuais e negativos de seleção: fatôres econômicos, que atingem os que não podem continuar os estudos, chamados que são para o ganho de um salário que reforce os insuficientes orçamentos de suas familias; fatôres sociais, configurados pela ausência de motivação extra-escolar adequada que decorre das condições do meio familiar e comunitário; fatôres que podemos englobar na classificação genérica de pedagógicos, e que traduzem tôda sorte de desencontros entre o trabalho escolar e as características psicológicas dos alunos. A ação dêsses fatôres teria de refletir-se, comn efetivamente se reflete, em retardamento e evasão dos alunos.

Os dados das tabelas que adiante apresentamos, retratam as proporções alarmantes do fenômeno da evasão e retardamento no ensino secundário brasileiro. Nessas tabelas podemos acompanhar, desde o início do curso secundário até o seu término, a vida das gerações escolares que se sucedem de três em três anos, a partir de 1933. Vê-se de que modo, em cada geração escolar secundária, são eliminados, série a série, quantidades elevadas de alunos, os quais vão ficando em retardo sôbre os seus colegas de turma, ou abandonam a escola. Êste fenômeno deveria ser capaz, por si sòzinho, para destruir todo e qualquer entusiasmo quanto à «democratização» do ensino secundário brasileiro. E se alguém se apegasse ao argumento de que a eliminação representa o grau em que o ensino secundário é realmente seletivo, bastaria lembrar a insatisfação generalizada que a propósito dos vestibulares às escolas superiores, a chamada «decadência» do ensino secundário provoca. Na realidade, o que há não é nem «democratização» nem «decadência», mas um grave desajustamento entre as condições reais em que o ensino secundário opera e a finalidade teórica a que êle visa.

A evasão e o retardamento, no ensino secundário brasileiro, se manifestam desde a série inicial. E' verdade que, nesta série, o simples fato do trânsito, em geral precoce, dos alunos, do curso primário para outro de regime bem diferente, explica grande parte da eliminação e retardamento que se verificam nesta primeira série. E tanto assim é que a percentagem dos eliminados e reprovados, sôbre a matrícula, é, nessa série, superior às mesmas percentagens relativas às séries seguintes, em tôdas as gerações consideradas, até a de 1951-1957. Nesta, a percentagem relativa à terceira série é quase igual à relativa à série inicial. Na geração ginasial de 19541957 , a percentagem relativa à primeira série é pràticamente igual à relativa à segunda, que é muito elevada. Como se trata, neste caso, de dados provisórios, que podem ser alterados numa apuração definitiva, não devemos aventurar a interpretação de estar ocorrendo uma modificação substancial no comportamento estatístico das gerações secundárias mais recentes, comparadas com as anteriores.

Depois da queda que se observa na percentagem dos eliminados e retardados da $2^{\text {a }}$ série, comparada com a mesma percentagem na $1^{\text {a }}$ série, verifica-se que a tendência ao aumento desta percentagem, entre a $3^{\text {a }}$ e $4^{\text {a }}$ séries do «secundário fundamental» ( $1^{\circ}$ ciclo de acôrdo com a Lei Campos), e entre a $2^{\mathrm{a}}$ e $3^{\mathrm{a}}$ séries do ginásio atual, é um fenômeno constante, a traduzir o que a repetência e a evasão têm de fatôres essencialmente ligados às 
condições vigentes no ensino secundário. A compensar a constância do aludido fenômeno, há a relativamente baixa percentagem dos reprovados na série final, fato que se observa nas gerações que estudaram sob a vigência da Lei Campos, e que se repete nas gerações de 1942-1948 e 1945-1951, cuios estudos se vautaram pela vigente Lei Orgânica. No entanto, nas gerações de 1948-1954 e 1951-1957, a percentagem das reprovações na última série é bem elevada: respectivamente 15,9 e 16,2, para o ginásio e colégio, na primeira dessas gerações, e 17,7 para o ginásio, na última. Não dispomos de dados sôbre as conclusões do colégio em 1957, mas o fato aludido sintomatiza, possivelmente, um agravamento do desajuste entre a estrutura dos cursos e as condições e necessidades dos alunos, nos últimos anos.

Mas êsse desajustamento não é um fato novo, como revelam não só a média das percentagens de eliminação série a série, em tôdas as gerações estudadas, mas, também, e sobretudo, as percentagens da eliminação total em ambos os ciclos. Em média, as conclusões no ano têrmo do curso de primeiro ciclo das gerações consideradas, não ultrapassam $49,1 \%$ do total das matrículas na $1^{\text {a }}$ série, no ano inicial; considerando-se o segundo ciclo, a percentagem correspondente é apenas superior à procedente : $52,4 \%$. Ainda que, com relação ao segundo ciclo, não haja uma tendência muito nítida, no ginásio a percentagem de eliminação total tem crescido, de geração a geração, nas mais recentes das gerações consideradas, da seguinte forma: $51,0,52,4,55,0$. Esses números também sugerem um agravamento do desacôrdo entre o trabalho escolar e as condições necessidades dos alunos, nos últimos anos, ao menos com relação ao ginásio.

De modo geral, devemos notar que os dados coligidos nos quadros seriam mais significativos, e, também, mais impressionantes se separássemos,

QUADRO IV

RENDIMENTO DO ENSINO SECUNDARIO MEDIDO PELA OUEDA PERCENTUAL DA MATRICULA SERIE A SERIE E PELA DIFERENCA ENTRE A MATRICULA NA ULTIMA SERIE E IAS CONCLUSÕES DE CURSO, E ESTAS E A MATRICULA NA SERIE. INICIAL DO 2. CICLO POR GE. RAÇÕES ESCOLARES

Gerą̧ão de 1933-1939

\begin{tabular}{|c|c|c|c|c|}
\hline \multirow{2}{*}{ ANOS } & \multirow{2}{*}{ SERIE E CURSO } & \multirow{2}{*}{$\begin{array}{l}\text { MATRICULAS E } \\
\text { CONCLUSÕES }\end{array}$} & \multicolumn{2}{|c|}{$\begin{array}{l}\text { ELIMINAÇÃo E RETARDAMENTO } \\
\text { SERIE A SERIE }\end{array}$} \\
\hline & & & Numeros absolutos & Percentagem \\
\hline $\begin{array}{l}1933 \\
1934 \\
1935 \\
1936 \\
1937 \\
1937 \\
1938 \\
1939 \\
1939\end{array}$ & 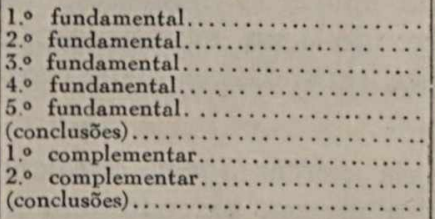 & $\begin{array}{r}20.468 \\
17.670 \\
16.245 \\
14.376 \\
12.024 \\
10.997 \\
7.797 \\
4.187 \\
3.630\end{array}$ & $\begin{array}{r}2.798 \\
1.425 \\
1.869 \\
2.352 \\
1.027 \\
3.200 \\
3.610 \\
557 \\
\end{array}$ & $\begin{array}{r}13.7 \\
8.1 \\
11.5 \\
16,4 \\
8,5 \\
29,1 \\
46,3 \\
13,3 \\
\end{array}$ \\
\hline
\end{tabular}

Media das percentagens de eliminąão serie a serie: $\ldots \ldots \ldots \ldots \ldots \ldots \ldots \ldots \ldots \ldots \ldots, 4$

Percentagem total de eliminação:

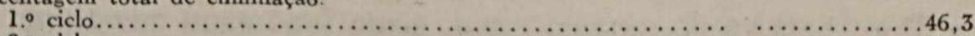

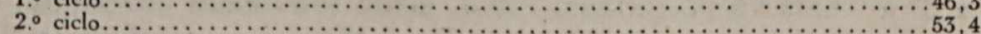

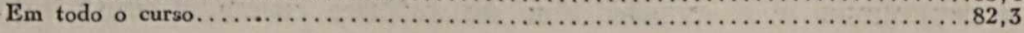


QUADRO V

Gerı̨̆ăo de 1936-1942

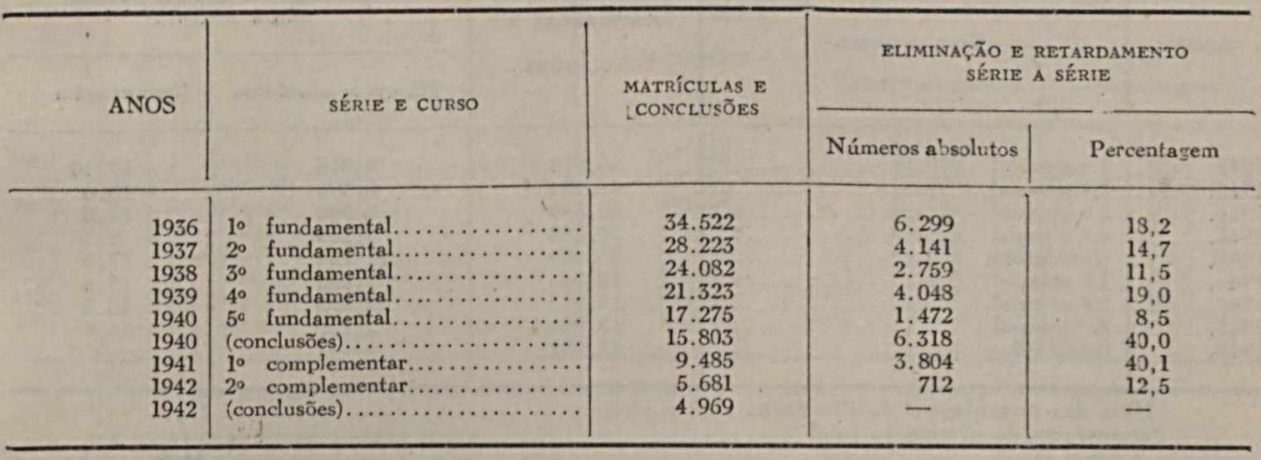

Média das percentagens de eliminação série a série.

20,6

Percentagem total de eliminação:

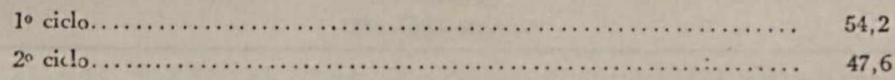

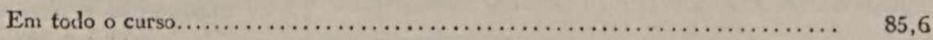

QUADRO IV

Gerą̧ão de 1939.1945

\begin{tabular}{|c|c|c|c|c|}
\hline \multirow{2}{*}{ ANOS } & \multirow{2}{*}{ SÉrIE E CURSO } & \multirow{2}{*}{$\begin{array}{l}\text { MATRÍCULAS E } \\
\text { CONCLUSÕES }\end{array}$} & \multicolumn{2}{|c|}{$\begin{array}{l}\text { ELIMINAÇÃO E RETARDAMENTO } \\
\text { SÉrIE A SÉRIE }\end{array}$} \\
\hline & & & Números absolutos & Percentagem \\
\hline $\begin{array}{l}1939 \\
1940 \\
1941 \\
1942 \\
1942 \\
1943 \\
1944 \\
1945 \\
1945\end{array}$ & 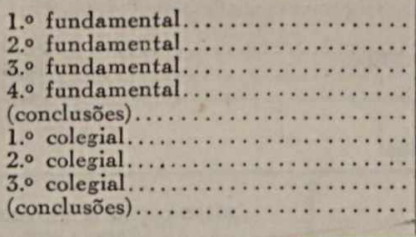 & $\begin{array}{rrr}44 & 014 \\
35 & 674 \\
31 & 128 \\
27 & 853 \\
& (* *) \\
12 & 111 \\
11 & 568 \\
8 & 964 \\
& (* * *)\end{array}$ & $\begin{array}{rl}8 & 340 \\
4 & 546 \\
3 & 275 \\
15 & 742 \\
& - \\
543 & (*) \\
2 & 604 \\
& -\end{array}$ & $\begin{array}{l}18,9 \\
12,7 \\
10,5 \\
56,5\left(^{*}\right) \\
15,3 \\
4,5 \\
22,5 \\
= \\
-\end{array}$ \\
\hline
\end{tabular}

Média das percentagens de eliminação série a série (excluída a

eliminação entre a matrícula e as conclusões na $4 a^{a}$ série fun-

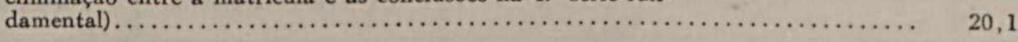

Percentagem total de eliminação

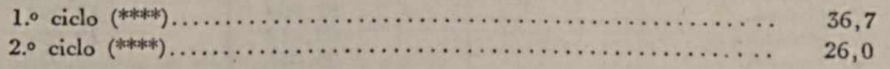

(*) Valor absoluto e percentual da diferença entre as matrículas na 4.a série fundamental e na primeira colegial.

(**) Em vista de neste ano ter sido promulgada a L. O. E. S. o S. E. E. C. reunia as conclusões da $4^{\text {a }}$. e $5^{n}$. séries fundamentais com o seguinte resultado: 42.400. Tendo a matrícula nestas duas séries em 1942, to talizado 50.043, a eliminação, portanto, foi de 7.643 o que representa $15,3 \%$ do total de matriculados nessas duas séries.

(****) Não dispusemos dos dados

(****) Até a matrícula na série final 
QUADRO VII

Geração de 1942-1948

\begin{tabular}{|c|c|c|c|c|}
\hline \multirow{2}{*}{ ANOS } & \multirow{2}{*}{ SÉRIE E CURSO } & \multirow{2}{*}{$\begin{array}{l}\text { MATRICULAS E } \\
\text { CONCLUSÕES }\end{array}$} & \multicolumn{2}{|c|}{$\begin{array}{c}\text { ELIMINAÇÃo E RETARDAMENTO } \\
\text { SÉRIE A SÉRIE }\end{array}$} \\
\hline & & & Números absolutos & Percentagem \\
\hline $\begin{array}{l}1942 \ldots \ldots \ldots \\
1943 \ldots \ldots \ldots \\
1944 \ldots \ldots \ldots \\
1945 \ldots \ldots \ldots \\
1945 \ldots \ldots \ldots \\
1946 \ldots \ldots \ldots \\
1947 \ldots \ldots \ldots \\
1948 \ldots \ldots \ldots \\
1948 \ldots \ldots\end{array}$ & 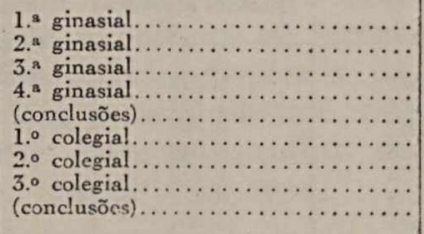 & $\begin{array}{l}56,910 \\
46,994 \\
40,598 \\
34,658 \\
31,509 \\
19,765 \\
15,913 \\
13,008 \\
11,301\end{array}$ & $\begin{array}{r}9,916 \\
6,396 \\
5,940 \\
3,149 \\
11,744 \\
3,852 \\
2,905 \\
1,707 \\
\end{array}$ & $\begin{array}{l}17,40 \\
13,6 \\
14,6 \\
9,1 \\
37,3 \\
19,4 \\
18,3 \\
13,1 \\
\end{array}$ \\
\hline $\begin{array}{l}\text { Méc } \\
\text { Perc } \\
\text { Enm }\end{array}$ & 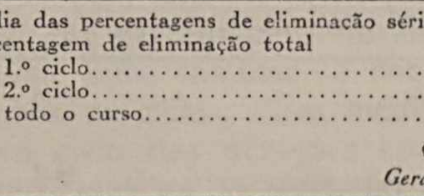 & $\begin{array}{l}\text { a série........ } \\
\ldots \ldots \ldots \ldots \ldots \ldots \ldots \\
\ldots \ldots \ldots \ldots \ldots \ldots \\
\ldots \ldots \ldots \ldots \\
\text { ADRO viII } \\
\text { Io } 1945-1951\end{array}$ & 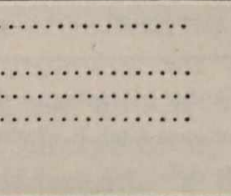 & $\begin{array}{l}17,5 \\
44,6 \\
42,8 \\
80,1\end{array}$ \\
\hline
\end{tabular}

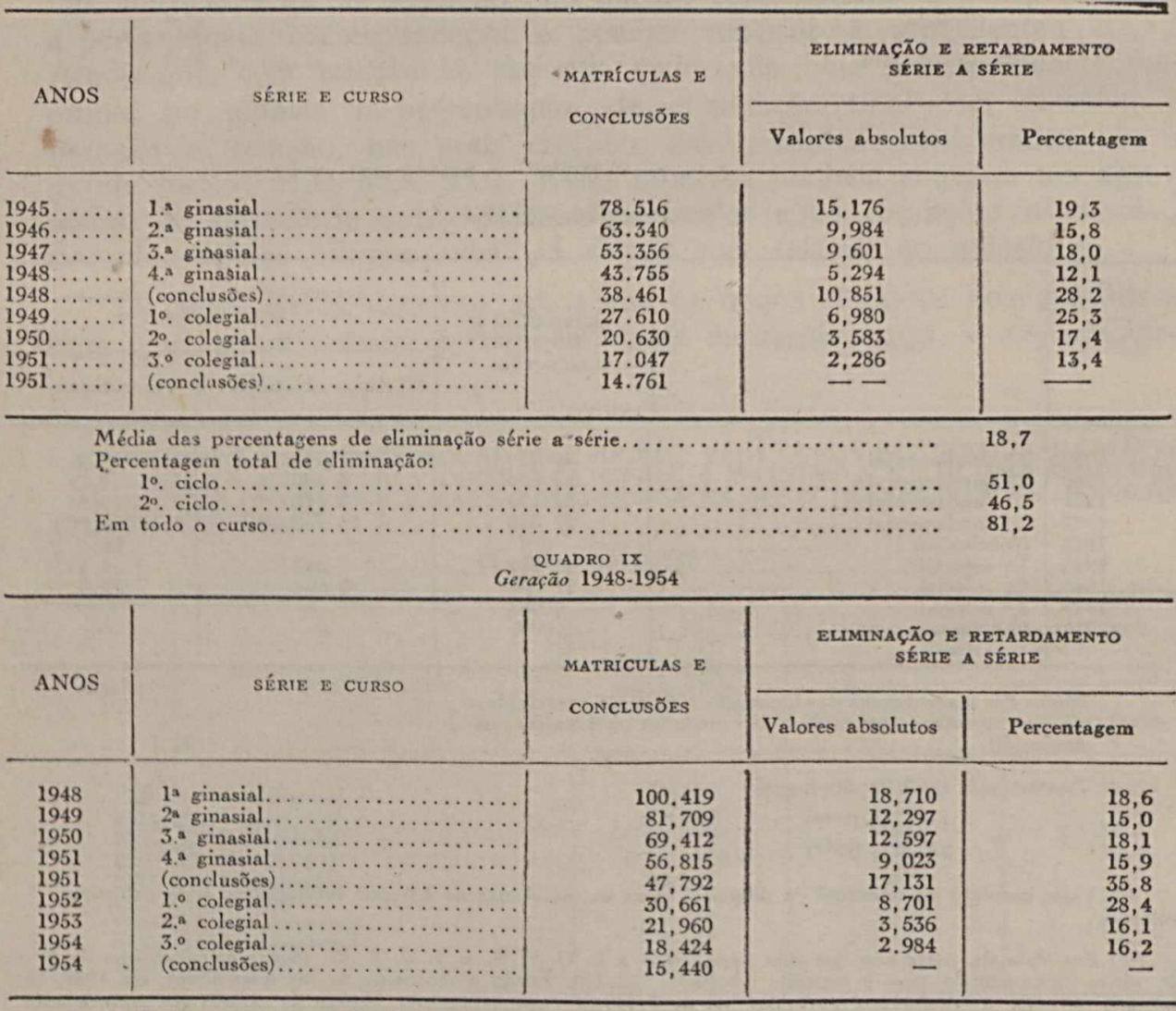

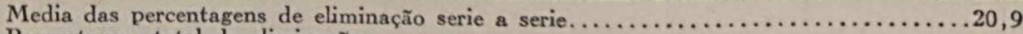

Percentagem total de eliminação:

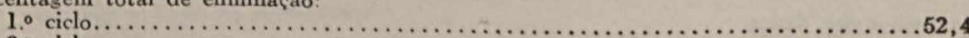

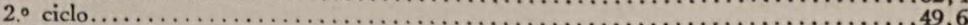

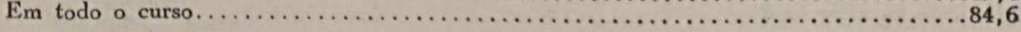


QUADRO $\mathrm{x}$

Geração 1951-1957

\begin{tabular}{|c|c|c|c|c|}
\hline \multirow{2}{*}{ ANOS } & \multirow{2}{*}{ SÉRIE E CURSO } & \multirow{2}{*}{$\begin{array}{l}\text { MATRICULAS E } \\
\text { CONCLUSÕES }\end{array}$} & \multicolumn{2}{|c|}{$\begin{array}{l}\text { ELIMINAÇÃo E RETARDAMENTO } \\
\text { SÉRIE A SÉRIE }\end{array}$} \\
\hline & & & Valores absolutos & Percentagem \\
\hline $\begin{array}{l}1951 \ldots \ldots \\
1952 \ldots \ldots \ldots \\
1953 \ldots \ldots \\
1954 \ldots \ldots \ldots \\
1954 \ldots \ldots \\
1955 \ldots \ldots \ldots \\
1956 \ldots \ldots \\
1957 \ldots \ldots \ldots\end{array}$ & 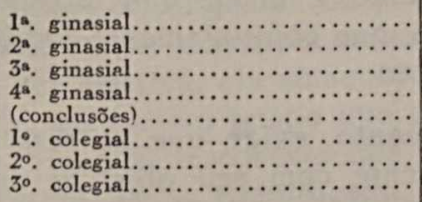 & $\begin{array}{r}134,323 \\
108,467 \\
91.658 \\
73,478 \\
60,439 \\
37,906 \\
25,530 \\
20,879\end{array}$ & $\begin{array}{l}25,856 \\
16,809 \\
18,180 \\
13,039 \\
22,533 \\
12,376 \\
4,651 \\
\end{array}$ & $\begin{array}{l}19,2 \\
15,5 \\
19,8 \\
17,7 \\
37,3 \\
32,6 \\
18,2 \\
\end{array}$ \\
\hline
\end{tabular}

Média das percentagens de eliminação série a série $\ldots \ldots \ldots \ldots \ldots \ldots \ldots \ldots \ldots \ldots \ldots \ldots \ldots \ldots$

Percentagem de eliminação total:

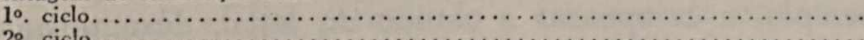
55,0

QUADRO XI

AS MAIS RECENTES GERAÇÕES QUE E POSSÍVEL ACOMPANHAR

\begin{tabular}{|c|c|c|c|c|}
\hline \multirow{2}{*}{ ANOS } & \multirow{2}{*}{ SÉRIES } & \multirow{2}{*}{ MATRÍCULAS } & \multicolumn{2}{|c|}{$\begin{array}{c}\text { ELIMINAÇÃO E RETARDAMENTO } \\
\text { SÉRIE A SÉRIE }\end{array}$} \\
\hline & & & Valores absolutos & Percentagem \\
\hline
\end{tabular}

GINísıo - 1954-1957

\begin{tabular}{|c|c|c|c|c|}
\hline $\begin{array}{l}1954 \ldots \ldots \\
1955 \ldots \ldots \\
1956 \ldots \ldots \\
1957 \ldots \ldots\end{array}$ & 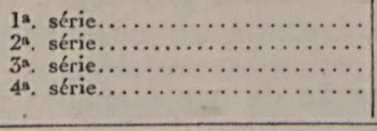 & $\begin{array}{r}175,594 \\
144.961 \\
115,700 \\
89,924\end{array}$ & $\begin{array}{l}30,633 \\
29,261 \\
25,776 \\
\end{array}$ & $\begin{array}{l}17,4 \\
20,2 \\
22,30 \\
-\end{array}$ \\
\hline \multicolumn{5}{|c|}{ CIENTf́FICO - 1955-1957 } \\
\hline $\begin{array}{l}1955 \ldots \ldots \\
1956 \ldots \ldots \\
1957 \ldots \ldots\end{array}$ & 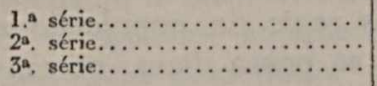 & $\begin{array}{l}32,505 \\
21,736 \\
17,720\end{array}$ & $\begin{array}{r}10,769 \\
4,016 \\
--\end{array}$ & $\begin{array}{l}33,1 \\
18,5 \\
-\end{array}$ \\
\hline \multicolumn{5}{|c|}{ CLÁSSICO - 1955-1957 } \\
\hline $\begin{array}{l}1955 \ldots \ldots \\
1956 \ldots \ldots \\
1957 \ldots \ldots\end{array}$ & $\begin{array}{l}1^{\mathrm{a}} \text {, série } \ldots \ldots \ldots \ldots \ldots \ldots \ldots \ldots \ldots \ldots \ldots \ldots \ldots \ldots \ldots \ldots \ldots \\
2^{\mathrm{a}} \text {. série } \ldots \ldots \ldots \ldots \ldots \ldots \ldots \ldots \ldots \ldots\end{array}$ & $\begin{array}{l}5,401 \\
3,794 \\
3,159\end{array}$ & $\begin{array}{r}1,607 \\
635 \\
-\end{array}$ & $\begin{array}{l}29,8 \\
16,7 \\
-\end{array}$ \\
\hline
\end{tabular}

Média das percentagens de eliminação série a série:

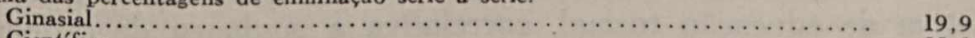

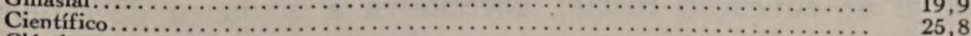

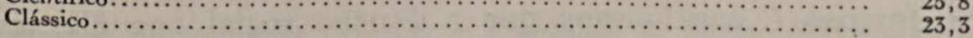

Percentagens da eliminação total:

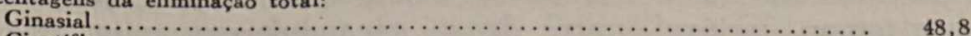

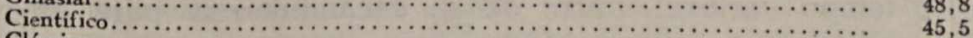

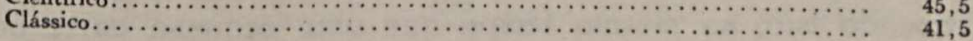

Nota: Os dados não registram as conclusõ̃es de curso. 
em cada série, os alunos novos dos alunos que se matriculam como repetentes da série. Em cada ano e série, de fato, a matrícula total é composta dos alunos da mesma geração que foram promovidos da sére anterior, e dos das geraçôes precedentes que, reprovados pela primeira ou por mais de uma vez, passam a estudar com essa geração mais nova. Se fizéssemos a separação entre uns e outros, os fenômenos da repetência e da eliminação pròpriamente dita, que chamaríamos então de evasão, apareceriam com seus índices numéricos respect.vos, o primeiro, como o segundo, e desde que ultrapasse certo valor razoável, revelando o desajustamento, que conjuntamente indicam, entre o trabalho escolar e as condições dos alunos.

O pleno significado dêsse desajustamento, exige que se ressalte que o currículo do curso secundário, coerentemente com seu objetivo de "preparação de individualidades condutoras", é um currículo sobrecarregado de matérias que, salvo o suposto valor formativo, apenas têm valor se o seu estudo prossegue até o fim e com vistas aos cursos de nível superior. No ginásio, por exemplo, a compensar o estudo do latim, durante quatro anos, o do francês por igual tempo, o do inglês por três anos, o da história estrangeira por três anos, há, sòmente, de direto e indiscutivel valor prático, além do português e da matemática, as ciências naturais e os trabalhos manuais. Assim, os alunos que abandonam os cursos ao meio, vão para as ocupações ativas ou para os cursos de preparação profissional equipados com estudos precários de matérias sem nenhuma relação, a maioria delas, com os novos estudos que vão fazer, ou com as atividades que vão exercer. E que dizer dos que concluem os cursos de $2^{\circ}$ ciclo? As reprovações dos candidatos aos exames vestibulares das escolas superiores, a que sòmente se expoem, aliás, depois da preparação intensiva nos cursos especializados na espécie de "chauffage" que êsses exames exigem, bem como as periódicas gritas contra a "decadência" do ensino secundário, que êsses exames provocam, respondem a essa pergunta.

Diante dêsses fatos, é irrecusávél a afirmação de que o ensino secundário não está cumprindo a sua finalidade de formação educativa de uma elite. Tal tarefa, para ser convenientemente realizada, exigiria condições mais racionais de organização escolar, em face das quais um tão flagrante desajustamento entre o trabalho didático e as características reais da população que a êle se suhmete, não se verificariam. Ou, talvez, se possa dizer, no máximo, que essa finalidade está sendo alcançada, mas sòmente em relação a uma minoria insignificante dos que procuram os ginásios e colégios, à custa, portanto, de um enorme desperdicio representado pela massa dos que nêles ingressam, porém, mais cedo ou mais tarde, são rejeitados por um mecanismo impiedoso de seleção.

Mas, se o crescimento do ensino secundário manifesta a maior necessidade objetiva de educação formal, correlativa a mudança de ordem social e econômica, forçoso é concluirmos que a função social que êle vem preenchendo, para a maioria dos educandos, é a de mantê-los na escola, de qualquer modo e por tempo variável, antes de se encaminharem para as ocupações ativas. Fazendo isto, ao mesmo tempo que uma pequena parte dos alunos é selecionada para os cursos de nível superior, a função do ensino secun- 
dário, para o conjunto dos alunos, pode ser descrita como de distribuição, isto é, de encaminhamento dos jovens para prosseguimento dos estudos ou para o trabalho, de acôrdo com suas condições sociais e capacidades psicológicas.

Essa função de distribuição se reparte entre o ensino secundário e os outros ramos do ensino médio, aos quais, contudo, tanto do ponto-de-vista das conveniências dos alunos, como do ponto-de-vista do interêsse social e nacional, maiores contingentes de jovens deveriam ser encaminhados. Sendo a função distributiva desempenhada, principalmente, por uma escola que se destinava a ser seletiva, ela sòmente pode ser satisfeita de um modo precário e tumultuado, ao mesmo tempo que um dos aspectos particulares do trabalho distributivo, que é a descoberta dos lideres potenciais e sua conveniente formação educativa, vê-se prejudicado ou anulado por efeito dos fatôres aleatórios de seleção.

Fazer com que, na educação pós-primária ou média, a função distributiva seja exercida de modo eficaz, permitindo a conveniente orientação dos alunos para as atividades sociais que mais lhes convenham e para as quais tenham melhores aptidões - é êste o problema prático para a solução do qual a reforma de qualquer dos seus ramos ou do conjunto do ensino médio deve contribuir. (14)

\section{A expansão do ensino secundário e a quebra do padrão de uniformidade}

A necessária reforma do ensino secundário brasileiro, como a reforma de qualquer outro grau ou ramo de nossa estrutura educacional, representará, certamente, o abandono daquela preocupação de uniformidade de tôdas as escolas que, ao longo de nossa evolução pedagógica, vem crescentemente marcando a legislação escolar brasileira. Realmente, a análise da evolução e presente situação da educação brasileira, especialmente no que se refere ao ensino secundário e superior, inevitàvelmente conduz a que se ressalte o propósito de imposição de um padrão de rigorosa uniformidade sôbre o conjunto de tôdas as escolas do país, como uma de suas feições essenciais. E feição tanto mais digna de registro quanto, em pràticamente todos os graus e ramos de ensino a iniciativa privada desempenha amplo papel de criação e manutenção de escolas, as quais se devem igualmente submeter ao padrão uniforme decretado pelo poder público.

No campo do ensino secundário, em especial, a peculiaridade dessa situação se torna mais gritante, porquanto o propósito de uniformização parte do Govêrno central, que, mantendo um único estabelecimento de ensino, impõe êsse padrão uniforme de organização e funcionamento às escolas secundárias mantidas pelos governos estaduais, que são a minoria, e às escolas particulares, que são a esmagadora maioria. Aliás, a simples predominância do ensino

(14) Geraldo Bastos Silva, Situação e Problemas do Ensino Secundário, conferência pronunciada na reuniăo de estudos de diretores de estabelecimentos de ensino secundário promovida pela Inspetoria Secional do Distrito Federal, em 1957, reproduzida em "O Observador Econômico e Financeiro", n 268, junho de 1958, e na revista "Acaiaca", de janeiro de 1958 . 
particular sôbre o público - federal, estadual e municipal - já é, por si sòzinha, uma característica peculiar do ensino secundário brasileiro, uma característica que configura uma situação absolutamente diversa da de outros países, nos quais a massa dos alunos está em escolas médias públicas e sòmente a minoria dos filhos de famílias que desejam uma educação marcada por certo sentido de seletividade social se matricula nas escolas privadas.

De modo geral, isto é, com referência ao conjunto de todos os graus e ramos de nosso ensino, com exclusão do profissional e do superior, a combinação de imposição de um padrão uniforme com a maior ou menor, mas sempre ponderável iniciativa privada, traduziu a combinação dos fatôres de ordem política, econômica e cultural que presidiram a formação de nosso sistema escolar. Quanto ao fator político, houve desde o início de nossa vida independente, senão antes, a preocupação de assumir o Estado um papel pioneiro em matéria de difusão do ensino. Do ponto-de-vista econômico, no entanto, a circunstância de nossa estrutura econômica, até data recente predominantemente agrária, e da conseqüente baixa renda nacional, limitaram o êxito da ação pública de criação e desenvolvimento da estrutura escolar. Finalmente, do ponto-de-vista cultural, faltou-nos um espírito de iniciativa local que permitisse o desenvolvimento escolar como empreendimento das comunidades.

Em vista dêsses fatôres, produziu-se segundo linhas muito especiais a inevitável repartição, entre o poder público e a iniciativa privada, da responsabilidade de promoção do desenvolvimento escolar. De uma parte, o poder público tem sido até hoje, quase exclusivamente, os governos central e regionais (provinciais e estaduais), cujas atividades assumiram uma forma centralizada (de âmbito nacional, no caso do govêrno central, ou de âmbito regional, no caso dos govrenos provinciais ou estaduais). De outra parte, as mesmas condições culturais que determinaram a quase ausência total do poder público local, bem como de órgãos não governamentais das comunidades, na iniciativa do desenvolvimento escolar, levaram a que a iniciativa privada se caracterizasse menos pelo intento de exercer atividade pedagógica livre do contrôle estatal, para fins de proselitismo religioso ou outro, do que pelo simples espírito de emprêsa, sem qualquer outra preocupação que a de uma simples prestação remunerada de serviço. Finalmente, uma das características mais salientes da ação centralizadora consistiu na imposição de padrões uniformes em tôda a extensão das respectivas áreas, sem que houvesse previsão de ajustamento dêsse padrões à diversidade de situações locais. Como conseqüência, a adaptação mais ou menos simulada, ou mais ou menos formal, a tais padrões se tornava a aspiração máxima das escolas particulares no seu afã de prestigiar ou valorizar, em face de seus clientes, o serviço que forneciam, mediante o visto ou fiscalização do poder público. (15)

Não queremos discutir, neste momento, o problema dessa sui generis centralização normativa e fiscalizadora, exercida pelo Govêrno federal, que se verifica no ensino secundário brasileiro. Diremos sòmente que, a nosso ver,

(15) Educação e Desenvolvimento Nacional, cit. p. 16. 
êsse tipo de centralização não é, em si mesmo, incompativel com as indispensáveis modificações de organização e funcionamento de que carece a educação média brasileira. O ponto que nos parece insuscetivel de discussão, quer se advogue a continuidade da centralização normativa e fiscalizadora do Govêrno federal, quer se pleiteie a adoção de una estrutura descentralizada de organização escolar, reside em que a forma e o conteúdo da indispensável ação do poder público devem mudar radicalmente de qualidade. $E$ isto não sòmente por exigência doutrinária, de natureza politica ou pedagógica, mas por imposição dos próprios fatos, da própria realidade atual da situação do ensino secundário brasileiro.

$\mathrm{Na}$ verdade, malgrado a circunstância de, desde 1942, estar em vigor uma legislação que, exacerbando tendência que the foi anterior, levou a um grau extremo a preocupação de uniformizar a organização e o funcionamento de tôdas as escolas secundárias do país, a expansão do ensino secundário representou a efetiva negação da pressuposta uniformidade dessas escolas. A expatısão do ensino secundário, tendo resultado em a negação de seu desejado papel seletivo, constituiu também a quebra do padrão de uniformidade que se pretendeu impor às escolas. Uma e outra coisa, realmente, foram as duas faces de um mesmo fenômeno, cujas condições administrativas anteriormente indicamos: a falência da administração federal em efetivar uma politica de ensino secundário coerente com os principios pedagógicos consubstanciados na legislação.

É incontestável, no entanto, que nessa quebra do padrão de uniformidade temos o lado mais grave, por suas consequiências, dêsse mesmo fenômeno de que a perda do caráter seletivo do ensino secundário é o reverso. É justamente porque tôdas as escolas não são uniformes ou iguais, como se continua a presumir, que o ensino secundário não é seletivo, como se desejou. Não queremos dizer, com isto, que todo ensino seletivo deva ser uniforme. Mas, se se tenta organizar a função seletiva à base da uniformidade de ensino, a falência desta uniformidade acarreta a da função seletiva, e isto da forma mais desastrosa. As escolas conferem os direitos ou prerrogativas que decorrem de sua suposta função seletiva, sem que esta seja realmente preenchida, mas pelo fato de que elas - aparentemente, formalmente, - obedecem ao padrão de uniformidade que se associa com essa função. A ênfase sôbre a uniformidade desloca-se dos aspectos que, pedagògicamente, seriam relevantes, para aquêles outros puramente acessórios, extrínsecos.

Essa é, exatamente, a situação que gerou a expansão do ensino secun dário e, ao mesmo tempo, dela resultou. Certamente que, como aspecto complementar, ainda que não acidental dessa situação, está o fato de que a expansão do ensino secundário se tenha dado, preponderantemente, pelo impulso da iniciativa particular, enquanto o poder federal, que impunha a uniformidade, limitava-se a manter um colégio-padrão, ao qual as outras escolas eram equiparadas. Como êste poder não teve - outros dirão que não podia ter - a capacidade de dar autenticidade à equiparação, na base de critérios educacionalmente relevantes, passaram a prevalecer os critérios extrinsecos, isto é, aquêles formalmente verificáveis. Do ponto-de-vista imediatista que inspirou a iniciativa particular, o resultado foi perfeitamente satisfatório, porquanto possibilitou que, no vácuo gerado pela carência de 
iniciativa pública criadora de instituições escolares, as escolas dela resultantes crescessem e se multiplicassem, prestigiadas por sua condição de escolas oficializadas.

Com a uniformização imposta pelo Govêrno federal e associada à atribuição de uma função seletiva ao ensino secundário, estava "aberto o caminho para a expansão escolar descompassada, a que assistimos em todo o país, nos últimos vinte anos", como diz Anísio TeIxeIra. Nessa expansão, realmente, o maior contingente foi constituido por uma escola secundária, como diz ainda Anísio Teixeira, "regularmente uniforme e rigida, de caráter acadêmico e portanto fácil de criar e fazer funcionar, bem ou mal (mais mal do que bem), com o privilégio de escola única ou de passagem única para o ensino superior (passagem naturalmente ambicionada por todos os alunos), entregue ou largada, tão privilegiada e atraente escola, à livre iniciativa particular, mediante concessão pública, facilitada sob aleatórias condições e aleatórios contrôles, rígidos apenas no papelório e, quanto a êste, sob a complacência protetora de uma tôda-poderosa burocracia central e centralizadora". (16)

Ao focalizarmos êsses aspectos da situação do ensino secundário brasileiro, não podemos deixar de continuar citando e comentando Anísio TeixeIra, de quem um dos maiores méritos tem sido o da crítica justa e impiedosa, como se faz mister, de certas características negativas do sistema escolar brasileiro, de características que no ensino secundário têm, precisamente, a sua exemplificação mais perfeita. De modo geral, na verdade, o sistema educacional brasileiro, como diz Anísio TeIXeira, "é um sistema artificial de ensino, desligado da realidade e da cultura ambiente, com um currículo uniforme, fixado por lei, e até programas uniformes e também oficiais, rígidos". Mas, como acrescenta Anísio Teixeira, "êste sistema está sendo liquidado pela expansão escolar desabrida" (17). No ensino secundário, "a despeito da enorme resistência que estão oferecendo à transformação dessa escolà linear, uniforme e rígida, segundo o figurino legal impôsto a todo o vasto e já tão diversificado país, a escola secundária vai-se fazer uma escola média vária, diversificada, múltipla, heterogênea". (18)

Mas, antes que êsse desiderato se cumpra, isto é, antes que, também na lei, se abandone o padrão uniforme e rígido que, na realidade, já ficou há muito sem vigência, salvo nos seus aspectos meramente formais, ou antes que se resolva essa contradição entre os padrões legais do "ensino secundário" e os padrões efetivos pelos quais se regem os ginásios e colégios brasileiros, continuará a educação nacional a pagar o tributo de falsificação e inautenticidade que essa contradição exige: Realmente, como diz ainda Anisio Teixeira, "a oficialização, pelo regime de equiparações, de todo o ensino, particular e público, sob um modêlo uniforme e rigido, fiscalizado tão sòmente nos seus aspectos extrinsecos, não só permite como promove

(16) Anísio Terxeira, A crise educacional brasileira, Rev. Bras. de Estudos Pedagógicos", n. . $^{2} 0$.

(17) Idem, Padrồes brasileiros de educação e cultura, ibid., n. 55 .

(18) Idem, A escola secundária em transformação, ibid., n. 53. 
a falta de autenticidade do ensino nacional. A imposição do modêlo único cria a contingência da falsificação. Não sendo possível por falta de recursos materiais e humanos, na imensa heterogeneidade e diversificação das situações brasileiras, a realização do modêlo de modo adequado e eficiente, surgem os arranjos, as acomodações, os expedientes, quando náo a pura e simples falsificação de listas de professôres ou equipamentos. Criada esta situação, a fiscalização puramente formal a sanciona, e o ciclo de inautenticidade real do processo de ensino se fecha para qualquer movimento de saúde, renovação ou progresso educativo, tendendo antes a agravar os vícios de origem do que remediá-los".

É indiscutivel que na raiz dessa situação de inautenticidade do ensino secundário brasileiro está a circunstância da predominância do ensino particular sôbre o público. Justifica-se que voltemos a salientá-la, pois é uma circunstância que freqüentemente se invoca para legitimar o caráter rígido e uniformizador do contrôle federal do ensino secundário. Parte-se do fato de que, em grande parte dos estabelecimentos, o caráter de emprêsa predomina sôbre o de agências educativas. Sem querermos desenvolver a tese, que julgamos certa, de que para têrmos uma verdadeira educação secundária, é realmente necessário estimular-se a tendência ao crescimento do ensino secundário público, insistamos em que foi sob a vigência de uma estrutura pedagógica rígida e uniformizadora que se criaram todos os problemas que hoje afetam o ensino secundário. É legítimo, portanto, que se pretenda procurar na mudança de tal tipo de estrutura a solução dos problemas criados na sua vigência.

Em resumo, a atual estrutura do ensino secundário brasileiro, com tôda sua rigidez pedagógica, deu ensejo a que se estabelecesse uma padronização puramente formal das escolas secundárias. Essa padronização é, de fato, aparente, pois, por trás da uniformidade pressuposta, há diversidade real de escolas. Sobretudo, esta diversidade se traduz menos pelo elevado padrão de ensino de algumas escolas secundárias, do que pela nivelação de grande número na mediocridade e na simulação pedagógica. A substituição da uniformidade pela flexibilidade de organização, além de necessária para abrir a possibilidade de um melhor atendimento das diferenças individuais entre os alunos, 'condição do preenchimento da função distributiva das escolas médias, tem uma outra vantagem potencial que é a de permitir aos bons colégios e ginásios a experimentação de formas vivas e autênticas de trabalho educativo. Isto, evidentemente, envolve o risco de continuarem a existir as más escolas secundárias, aquelas em que as deficiências de tôda ordem limitam ou impedem qualquer esfôrço decisivo de aperfeiçoamento. A êste propósito, contudo, convém lembrar que, mesmo sob a vigência das regulamentações uniformizadoras e rígidas, no que, paradoxalmente se pode chamar o regime de igualdade de tôdas as escolas perante a lei, as diferenças de padrões reais, não só técnicos como até mesmo morais, se verificam. (20)

(19) Idem, O projeto de lei das diretrizes e bases da educação nacional, ibid.

(20) Situação e problemas do ensino secundário, in "O Ỏbservador Econômico e Financeiro", número citado. 
O problema da qualidade do ensino, como todos os problemas de educação, não depende apenas, para sua solução, da lei. Exige, além desta e de regulamentos adequados, a atividade dos administradores e a capacidade profissional dos educadores, uns e outros ajudados por uma opinião pública devidamente esclarecida por êles próprios. E' um problema de engenharia social, ou de política, no melhor sentido da expressão. E, sobretudo, exige também a focalização do problema realmente essencial a resolver, cuja compreensão, por sua vez, envolve a crítica das preconcepções e estereótipos resultantes de situações sociais ultrapassadas. 